\title{
THE RELATIONSHIP BETWEEN PERSONALITY PREFERENCES, SELF-ESTEEM AND EMOTIONAL COMPETENCE
}

\author{
MELINDE COETZEE \\ Coetzm1@unisa.ac.za \\ NICO MARTINS \\ Department Industrial and Organisational Psychology \\ University of South Africa \\ JOHAN S BASSON \\ Department Human Resource Management \\ University of Pretoria \\ HELENE MULLER \\ Research Support Unit \\ University of South Africa
}

\begin{abstract}
The relationship between leaders' personality preferences, self-esteem and emotional competence is the focus of this article. A study was conducted to analyse the responses of a sample of 107 South African leaders in the manufacturing industry to measures of the three constructs. The Myers-Briggs Type Indicator (MBTI), the Culturefree Self-esteem Inventories for Adults (CFSEI-AD), and the $360^{\circ}$ Emotional Competency Profiler (ECP) were administered. Positive relationships were found between the three constructs. The self-esteem construct appeared to be a more reliable predictor of emotional competence than the MBTI personality preferences. The findings of the study make an important contribution to the expanding body of knowledge concerned with the evaluation of personality variables that influence the effectiveness of leaders.
\end{abstract}

Key words

Emotional competence, emotional intelligence, leader development, personality preferences, self-esteem

The global, competitive and multi-cultural environment in which leaders operate places higher demands on their ability to understand and manage the impact of emotions and related behaviours in terms of organisational success (Higgs, 2001; Kinicki \& Kreitner, 2006; Martin, 2005). The focus of leader development is therefore increasingly shifting to the enhancement of leader attributes such as self-management, self-motivation, healthy self-esteem, and the capacity for interrelating emotionally intelligent with others in specific socio-cultural contexts (Coetzee, 2005; Dearborn, 2002; Lopes, Salovey, Cote \& Beers, 2005). These trends have led to a renewed interest in personality traits and the role of emotions in organisational life (Kinicki \& Kreitner, 2006; Lee \& Klein, 2002). In agreement with this, a number of authors emphasise the importance of individual personality traits as a means of predicting a leader's behaviour and the contribution of leaders' emotional intelligence to organisational effectiveness (Ashkanasy \& Daus, 2005; Carr, De la Garza \& Vorster, 2002; Du Toit, Coetzee \& Visser, 2005).

Knowledge of personality preferences enhances individuals' selfunderstanding and development, stress management, interpersonal communication, problem-solving and decisionmaking (Kennedy \& Kennedy, 2004). Self-esteem, as a personality trait, has also been indicated as an important selfactualising characteristic of effective leaders (Coetzee, 2005; Hewitt, 2002). Self-esteem includes internal, private feelings and self-consciousness that influence emotionally healthy functioning in the social context (George, 2000). Because leaders are in positions of being looked up to as role models, their behaviour is noted and absorbed by those around them, although not necessarily consciously, and are reflected throughout the entire organisation by those they influence (Dearborn, 2002).
Emotionally intelligent leaders are thought to achieve greater overall organisational performance (Miller, 1999). They appear to be more committed to their organisation, and use positive emotions to envision major improvements in organisational functioning (Palmer, Gardner \& Stough, 2003). Studies conducted by Lopes, Brackett, Nezlek, Schutz, Sellin and Salovey (2004) and Lopes, Salovey, Cote and Beers (2005) have demonstrated that the ability to manage emotions contributes positively to the quality of social interactions and decision-making of leaders. Emotionally intelligent leaders seem to be able to instill a sense of enthusiasm, trust and co-operation within and amongst employees (George, 2000; Stuart \& Pauquet, 2001). Collins (2001) found that the subordinates of leaders with higher emotion management skills demonstrated higher organisational commitment.

The factors underlying a leader's ability to demonstrate emotionally intelligent behaviour appear to be varied and complex (Dulewicz \& Higgs, 1999; Eisenberg, Cumberland, \& Spinrad, 1998; Higgs, 2001). According to the cognitiveaffective theories of Mischel (1999) and Worline, Wrzesniewski and Rafaeli (2002), behaviour is shaped by personal dispositions plus a person's specific cognitive and affective processes which may include perceptions of and feelings about themselves in a particular situation that is meaningful to them. Behaviour is a product of both the situation and stable personality traits. However, personal qualities (such as people's beliefs of what they can do, their plans and strategies for enacting behaviours, their expectancies for success, their self-concept, their positive and negative feelings about themselves, their needs based on their personality preferences, and their self-regulating strategies) will override situational variables. 
This study sets out to determine the relationship between three behavioural-related variables that form part of personality attributes that have an influence on a leader's effectiveness in the workplace. Limited research has been done to study the association between personality preferences, self-esteem and emotional competence. Although personality preferences, self-esteem and emotional intelligence represent distinct constructs, research has indicated that these behavioural-related variables are likely consequences of each other (Coetzee, 2005). A study conducted by Garrety, Badham, Morrigan, Rifkin and Zanko (2003) showed that leaders' awareness of their personality preferences helped them to learn how to express emotionally intelligent behaviour in interpersonal discussions with others. Research by (Higgs, 2001) has also indicated a strong relationship between personality preferences and the emotional intelligence of leaders. Ciarrochi, Chan and Caputi (2000), and Schutte, Malouff, Simunek, Hollander, and McKenley (2002) found that emotional intelligence and self-esteem were positively related, with higher emotional intelligence being associated with positive mood and higher self-esteem. Self-esteem can influence cognitive and affective responses of leaders, which may inhibit the demonstration of emotionally intelligent behaviour in the workplace.

This study therefore aims to investigate how personality variables such as personality preferences (as measured by the Myers-Briggs Type Indicator) and self-esteem may be related to leaders' emotional competence. In the context of this research, emotional competence is viewed as the observable emotional intelligence abilities, traits and behaviours which assist individuals in dealing creatively with a personally and professionally demanding environment and which result in outstanding performance at work (Goleman, 2001; Saarni, 1997). The findings may prove useful for Industrial Psychologists and human resource practitioners in understanding how personality factors influence leaders' ability to demonstrate emotionally intelligent behaviour in the workplace.

\section{Emotional competence}

The concept of emotional competence encompasses individuals' ability to demonstrate emotionally intelligent behaviour (Eisenberg et al., 1998; Goleman, 2001). The term emotional intelligence was originally coined by Salovey and Mayer (1990) to complement the traditional view of general intelligence by emphasising behaviour that requires emotional and behavioural control in social situations (Kanfer \& Kantrowitz, 2002). Although the construct is still in a stage of active development, four findings are emerging that provide an early picture of emotional intelligence: (1) emotional intelligence is distinct from, but positively related to, other intelligences, more specifically, it is the intelligence (the ability to grasp abstractions) applied to the life domain of emotions; (2) emotional intelligence is an individual difference, in the sense that some people are more endowed and others are less so; (3) emotional intelligence develops over a person's life span and can be enhanced through training; and (4) emotional intelligence involves particular abilities to reason intelligently about emotions including identifying and perceiving emotion (in oneself and others), as well as the skills to understand and to manage those emotions successfully in social situations (Ashkanasy \& Daus, 2005; Locke, 2005).

In this regard then, Mayer and Salovey's (1997) well-known ability model of emotional intelligence broadly describes the term as the ability to effectively join emotions and reasoning and using emotions to facilitate the intelligent reasoning about emotions to promote emotional and intellectual growth. Generally, emotionally intelligent behaviour is directed at successfully achieving personal life goals, solving problems important to one's emotional well-being, survival and social role performance (Bar-On, 1997; Fox \& Spector, 2000).

Emotions are generally regarded as the primary motivating forces that arouse, direct and sustain activity (Stuart \& Pauquet, 2001). Emotional intelligence therefore describes the extent to which individuals are able to tap into their feelings and emotions as a source of energy to guide their thinking and actions (Salovey \& Mayer, 1990). Furthermore, emotional intelligence involves individuals' ability to cognitively manage their emotional life with greater or lesser skill (Stuart \& Pauquet, 2001). This skill entails a unique set of competencies described by the so-called mixed models of emotional intelligence (Mandell \& Pherwani, 2003; Wolmarans, 2002) and includes for example competencies such as the following:

- Emotional literacy (individuals' awareness and understanding of their own and other people's emotions);

- Self-regard (individuals' assessment of and respect for their own worth as an equal human being);

- Self-management (individuals' ability to manage stress and harness energy to create a state of wellness and healthy balance between body, mind and soul);

- Self-motivation (individuals' ability to create a challenging vision and set stretching goals; to remain focused and optimistic in spite of setbacks; to take action everyday and remain committed to a cause; and to take responsibility for one's successes and failures);

- Change resilience (individuals' ability to remain flexible and open to new ideas and people, advocating the imperative for change and innovation when appropriate, with due concern and consideration for the emotional impact of change on people);

- Interpersonal relations (individuals' intuitive understanding of, and deep level of caring and compassion for people; a real concern for their well-being, growth and development, and joy and recognition for their successes); and

- Integration of head and heart (individuals' ability to make decisions and solve problems with due consideration of both facts and feelings, and with the commitment to create winwin solutions that serve both the goals and the relationships concerned (Wolmarans \& Martins, 2001).

According to Dulewicz and Higgs (2000), the notion of emotional competence implies that someone who has higher emotional intelligence has certain abilities and competencies that another person might not have. Individuals with well-developed emotional intelligence abilities and competencies can both negotiate their way through interpersonal exchanges and regulate their emotional experiences in a variable and challenging socio-cultural environment. Emotional competence implies also a sense of psychological well-being (a positive inner state of being) and an ability to skillfully, creatively and confidently adapt in an uncertain, unstructured, and changing socio-cultural environment (Goleman, 2001; Saarni, 1999; Wolmarans, 2002; Worline et al., 2002).

Although emotional intelligence develops over a person's life span and individuals' ability to demonstrate emotionally competent behaviour can be enhanced through training (Ashkanasy \& Daus, 2005; Locke, 2005) it is however, important to note that individuals are not always aware of why they are doing something, or what they are doing, because of the variety of defensive, displacement and screening processes that are related to aspects of their self-esteem. From this perspective many of people's emotions defy conscious control and regulation (Fineman, 2000). 


\section{Self-esteem}

The term "self-esteem" is commonly used to refer to the evaluations people make and maintain of themselves. It includes attitudes of approval or disapproval and the degree to which people feel worthy, capable, significant, and effective. Selfesteem is generally considered the evaluative component of the self-concept, a broader representation of the self that includes cognitive and behavioural aspects, as well as evaluative or affective ones (Garrety et al., 2003; Leary, 1999a; 1999b).

Various researchers anchor the concept of self-esteem in the realm of emotions by viewing the concept as a socially constructed emotion denoting feelings and perceptions about one's multiple self-concepts and self-images which are based on the psychological need for acceptance and belonging within one's social group, the desire for efficacious and authentic functioning, competence and achievement in comparison to other members of one's group (Battle, 1992; Baumeister \& Leary, 1995; Hewitt, 2002).

According to Battle (1992), the construct self-esteem comprises a number of facets or dimensions. He differentiates these selfesteem dimensions as general, social, and personal self-esteem for adults. General self-esteem is the aspect of self-esteem that refers to individuals' overall perceptions of and feelings about their worth; social self-esteem is the aspect of self-esteem that refers to individuals' perceptions of and feelings about the quality of their relationships with peers; and personal self-esteem is the aspect of self-esteem that refers to individuals' most innate perceptions and feelings of self-worth. When combined, these three subcomponents equal overall self-esteem.

As a socially constructed and experienced emotion, self-esteem is more a sign of well-being than a psychological trait (Hewitt, 2002). Self-esteem is a measure of individuals' expectations of positive events and, accordingly, their willingness to approach objects and others. Positive self-esteem is indicative of a positive and integral personal and social identity, that is, a sense that one is located securely in the social world, competent to meet its challenges, ready to participate in life with others, and able to balance social demands and personal desires (Garrety et al., 2003). A positive and integral sense of identity is crucially important because it is fundamental to the capacity for emphatic role taking, the capacity to see and to identify with the other's point of view. Positive and well-regulated mood, of which self-esteem is a key measure, is fundamental to the capacity to see virtue in others, good purposes in their action, and cooperative rather than competitive goals (Hewitt, 2002).

High self-esteem people are usually motivated to enhance their sense of self-esteem and will therefore behave more emotionally intelligent. They may also tend to present themselves in an unrealistically positive manner than are low self-esteem individuals, resulting in an overestimation in their selfevaluation of their emotional competence (Coetzee, 2005; Sosick \& Megerian, 1999).

People with low self-esteem may lack a firm, elaborate selfconcept, experience negative feelings about themselves, and find it difficult to present themselves in either a strongly positive or negative fashion. They may behave in a cautious, noncommittal fashion in their self-descriptions which may result in an underestimation of their self-evaluation of their emotional competence (Coetzee, 2005; Sosick \& Megerian, 1999; Tice, 1993).

\section{Personality preferences}

Jung's (1921) theory of psychological type explains that predictable differences in individuals are caused by differences in the way people prefer to use their minds to take in information, to organise that information and reach conclusions. His theory postulates two attitudinal orientations and four basic psychological functions (Jung, 1990). The attitudinal orientations comprise introversion (I) and extraversion (E) which relate to the focus of attention and flow or psychic energy of an individual. The extravert's attention is externally focused, whilst the introvert is inwardly focused.

The basic psychological functions relate to perceptual functions which mediate the way in which information is handled by the individual. Jung (1990) proposes that people develop one of two dominant preferences for information used in perceiving their world: sensation $(S)$ or intuition $(\mathrm{N})$. Sensation-dominant people prefer precise, specific data that is typically derived from their senses. In contrast, intuitiondominant people seek holistic information that reflects possibilities; the pattern of data is of more importance than the specific data points. Jung (1990) also proposed that people develop one of two dominant ways of judging information in order to reach decisions and take action: thinking (T) or feeling (F). Thinking-dominant people stress logic in their reasoning; they generalise and abstract. Feeling-dominant people stress value judgments in their reasoning; they think of things in human terms and emphasise how others may respond.

Implied in Jung's typology are two additional orientations relating to the way in which individuals approach the outer world in terms of judgment or perception. These were made explicit by Myers (1987), who labeled them as judging (J) and perceiving $(\mathrm{P})$. Judging was described as being related to the evaluation of external stimuli and an orientation to cope with these via structure and control. Perceiving was described in terms of receptivity to stimuli and seeking to understand and adapt to life based on these stimuli. By adding the judgingperceiving dichotomy, Jung's model was refined by Briggs and Myers (Myers, McCaulley, Quenk \& Hammer, 1998) so as to describe sixteen personality preference types. These sixteen personality preference types are measured by the Myers-Briggs Type Indicator (MBTI).

Combinations of the four attitudes (E-I and J-P) with the four functions (S-N, T-F), result in the following twelve combinations of personality preferences, namely EF-IF, ET-IT, ES-IS, EN-IN, EJIJ, EP-IP which are of concern to this study. According to Myers et al. (1998), combinations of the four attitudes (extraversion, introversion, judging and perceiving) and the attitudes extraversion (E) and introversion (I) with the dominant mental functions sensing-intuition (S-N) and thinking-feeling (T-F), identify particular type dynamics which provide practical and useful insights to researchers and practitioners. Higgs (2001) also contends that the dominant mental functions associated with differing types offer a more practical basis for analysis. In practice it is also extremely difficult to obtain a sufficiently large sample of all sixteen personality preference types to enable nonparametric statistical analyses to be conducted.

Against the foregoing background, the objective of this study was to establish whether leaders' emotional competence depended upon their self-esteem and personality preferences. More specifically, the goal was to determine whether:

- Personality preferences were related to leaders' self-esteem and emotional competence.

- Self-esteem was related to leaders' emotional competence.

- Personality preferences and self-esteem substantially predicted leaders' levels of emotional competence.

\section{RESEARCH DESIGN}

\section{Research approach}

A survey design was used to achieve the research objective (Shaughnessy \& Zechmeister, 1997).

\section{Participants}

The participants were a randomly selected sample of managers from three companies in the manufacturing industry. 
Participants were requested to randomly select three other individuals (either peers, superiors and/or subordinates) to evaluate them in terms of the $360^{\circ}$ Emotional Competency Profiler (ECP) measurements. In terms of the ECP selfevaluations, the Myers-Briggs Type Indicator (MBTI) and Culture-free Self-esteem Inventories for Adults (CFSEI-AD), a final sample size of 107 was achieved, and in terms of the ECP other evaluations, a sample size of 340 was achieved. In total, this gave a sample size of 447 .

The sample of 107 managers constituted 77\% White subjects, whilst females represented $21 \%$ of the sample. The age groups $<35$ to 45 years constituted $73 \%$ of the sample and the age group 46 and older $27 \%$ of the sample. Approximately $20 \%$ of the sample has more than 21 years of service at their company; $31 \%$ had between 11 to 20 years of service, whilst $49 \%$ had between 1 to 10 years of service.

The introversion-judging personality preferences were predominant in this sample (IJ 45\%; IS 32\%; IN 13\%), followed by the extraversion-judging personality preferences (EJ 35\%; ET $31 \%$; EF 4\%). Overall, the introversion-perceiving (IP 10\%; IT 6\%; IF 4\%) and extraversion-perceiving (EP 10\%; ES 3\%; EN 7\%) personality preferences were underrepresented in this sample.

\section{Measuring instruments}

Three instruments were used, namely the $360^{\circ}$ Emotional Competency Profiler (ECP) (Wolmarans \& Martins, 2001), the Myers-Briggs Type Indicator, Form G (MBTI) (Myers, 1980), and the Culture-free Self-esteem Inventories for Adults (CFSEI-AD) (Battle, 1992).

\section{$360^{\circ}$ Emotional Competency Profiler (ECP)}

The ECP was used to determine the participants' current emotional competence. The ECP questionnaire consists of the seven subscales and 46 items. The ECP uses two four-point Likert scales to measure levels of current emotional competence and the importance of those emotional competence behaviours to the individual being assessed. High scores on the current emotional competence behaviour scales indicate that the individual being assessed exhibits this behaviour. A high score on the importance of behaviour scale indicates that the particular emotional competence behaviour is important for the person being assessed. Low scores on the current behaviour scale indicate the absence of such behaviour, while low scores on the importance of behaviour scale indicate that the particular emotional competence behaviour is unimportant for the person being assessed. Only the current behaviour scale applied to the research as the concern was the actual demonstration of emotionally competent behaviour.

Content validity of the ECP was built into the instrument and tested by developing a construct definition of each emotional competence behavioural cluster. Items were written to cover all areas of the identified construct for each of the seven emotional competence clusters. Item analysis indicates that the items in the subtest clusters possess acceptable internal consistency (Wolmarans \& Martins, 2001).

Wolmarans and Martins (2001) report the following Cronbach alpha coefficients: Emotional literacy $(0,863)$; Self-esteem/Selfregard $(0,872)$; Self-management $(0,851)$; Self-motivation $(0,911)$; Change resilience $(0,933)$; Interpersonal relations $(0,953)$; and Integration of head/heart $(0,903)$. The overall reliability of the ECP was reported to be 0,981 .

\section{Myers-Briggs Type Indicator, Form G (MBTI)}

The well-established MBTI, Form G, was used for this research project to measure the personality preferences of the participants. The MBTI, Form G, is a self-reporting instrument and consists of three parts. Part I contains 26 items; part II, 45 items and part III, 55 items. Overall, the individual has to respond to 126 items. The MBTI is a questionnaire-style instrument consisting of items arranged in a forced-choice format. For each item, subjects are provided two responses to choose between. The objective of the MBTI is to classify an individual into one of the 16 personality types (Myers \& McCaulley, 1992).

While there are different views on many aspects of the validity of the MBTI, there is general agreement on its high levels of face validity (Costa \& McCrae, 1988; Dulewicz \& Higgs, 1999). Pinder and Herriot (1990) report that the functional attitude dichotomy of judgment-perception (JP) is found as being the strongest area of correlation between MBTI and other measures of personality, competency or behaviour. In presenting reliability results in the MBTI manual, Myers et al. (1998) have examined internal consistencies based on Alpha coefficients, none of which are below 0,7 for the MBTI scales. Test-retest reliabilities also show consistency over time.

Culture-free Self-esteem Inventories for Adults (CFSEI-AD) The CFSEI 2-AD was used to measure participants' self-esteem. The CFSEI-AD is a self-report inventory and contains 40 items with the following subscales: General self-esteem (16 items); social self-esteem ( 8 items); and personal self-esteem (8 items). When combined, these three sub-components equal total selfesteem and lie subtest items that indicate defensiveness ( 8 items) (Battle, 1992). The items in the instrument are divided into two groups, namely those that indicate high self-esteem and those that indicate low self-esteem.

Content validity was built into the instrument by developing a construct definition of self-esteem and by writing items intended to cover all areas of the construct. The factor analysis results presented by Battle (1992) indicated that the items in the subtests possess acceptable internal consistency. Means, standard deviations, and correlations for the total sample involved in the initial test-retest reliability study, indicate that the test-retest correlation for all subjects was 0,81 , for males and females, 0,79 and 0,82. Results presented by Battle (1992) indicate that correlations for the standardisation sample were significant for the total and all subtests as well.

A study conducted by Coetzee (2004) on the construct validity of the CFESEI-AD for Black and White South African adults supported the construct validity of the instrument. The Cronbach alpha coefficients of the item analyses on the total and subscales indicated a relatively high internal consistency reliability $(0,85)$. Furthermore, test-retest reliability showed that all the correlations are higher than 0,74 for each of the subscales and the total scale $(0,91)$. The sample population $(n=190)$ constituted $52.6 \%$ Whites and $47.4 \%$ Blacks which confirm the culture-free properties of the instrument.

\section{Procedure}

Permission was obtained from the managing directors of the three companies to execute the research in their respective companies. The participants were approached by their managers, who explained the reasons for the research to them. The randomly selected managers who were willing to participate in the research project were assembled in groups on predetermined dates. The rationale underlying the study and the process applicable to the completion of the questionnaires were explained to the participants. After the completion of the three questionnaires, the participants were then asked to identify at a random basis three individuals (peers, subordinates, or clients) to rate them on the ECP measurements. The completed ECP questionnaires by the three selected individuals were then collected at a predetermined date by the Human Resource Practitioner who assisted in the coordination of the distribution and collection of the questionnaires. Feedback was given to the participants on their results. The ECP was scored electronically, whilst the MBTI and CFSEI-AD were scored manually according the instructions of the authors thereof. 


\section{Statistical analysis}

The statistical analysis was carried out with the help of the SAS System, Version 9.1, statistical package (SAS Institute, 2000).

\section{Item analyses}

Item reliability and construct score internal consistency of the $360^{\circ}$ ECP were tested by means of item analysis and calculating Cronbach alpha coefficients to establish whether items grouped together within a specific construct. This was done for the current behaviour scale only to establish reliability and internal consistency between the self-evaluations and the other-evaluations.

The Cronbach alpha coefficients of $>0,71$ in Table 1 that were obtained for the self and other evaluation ECP constructs (with the exception of the Emotional Literacy Self - alpha $=0,51<0,7$, Self-esteem/self-regard Self- alpha $=0,67<0,7$ and Self-motivation Self - alpha $=0,61<0,7)$ were considered as acceptable.

Point bi-serial correlation coefficients

Since the MBTI personality preference scores are regarded as dichotomous data in this study, and the scores of the CFSEI-AD and $360^{\circ} \mathrm{ECP}$ are regarded as scale or continuous variables, point bi-serial correlations were chosen as the appropriate statistical procedure to investigate the relationship between the MBTI personality preferences and the CFSEI-AD self-esteem scales, and the ECP emotional competence scales respectively (Higgs, 2001).

A significance level of 0,05 was chosen as indication of significance. Point bi-serial correlation is in essence a t-test for the difference between two means, with the added advantage of the strength of the test included in the correlation. Significance of the correlation coefficient indicates that the two means - in this study, the means of the two members of the personality preference bi-polar pair - differ significantly from one another with regard to the particular score under investigation (see Table 3 and Table 5).

\section{Pearson product-moment correlation coefficients}

Since both CFSEI-AD and ECP scores are scale variables, Pearson product-moment correlations were calculated to investigate the relationship between the CFSEI-AD self-esteem scores and the ECP emotional competence current behaviour scores for both the self and other evaluations. The significance level of 0,05 was also chosen as indication of significance.

\section{Multiple linear regression}

To determine whether the ECP Total Emotional Competence Self scale can be predicted in terms of the MBTI personality preferences and the CFSEI-AD Total Self-esteem scale, separate multiple linear regressions were calculated for each personality preference pair. $\mathrm{F}(\mathrm{p})<0,05$ was chosen as indication of significance (Tredoux \& Durrheim, 2002).

\section{Analysis of variance}

One-way analyses of variance were conducted to establish whether the differences between self and other emotional competence ratings could be ascribed to self-esteem perceptions of the respondents. The general 0,05 significance level was also chosen for the ANOVA analysis.

\section{RESULTS}

The objective of this study was to investigate the relationship between the MBTI twelve dominant personality preferences (EFIF, ET-IT, ES-IS, EN-IN, EJ-IJ, EP-IP), the CFSEI-AD self-esteem constructs and the ECP emotional competence current behaviour constructs.

The first step in the analysis of the data was to investigate whether there were statistically significant associations between the MBTI personality preferences, the CFSEI-AD scales and the ECP scales. To test whether personality preferences were related to self-esteem and emotional competence, point bi-serial correlation coefficients were calculated. Investigation of Table 2 indicates that the MBTI extraverted-thinking (ET) and extraverted-intuitive (EN) personality preferences are significantly associated with the CFSEI$\mathrm{AD}$ social, general and total self-esteem scales. Table 3 indicates the direction and nature of the significant correlations. In terms of the ECP current behaviour self-evaluations, Tables 4 and 5 indicate that the ECP self-motivation scale is significantly associated with the MBTI extraverted-judging (EJ), extraverted-thinking (ET) and extraverted-intuitive (EN) preferences, while the ECP interpersonal relations scale is significantly associated with the extravertedintuitive (EN) and extraverted-feeling (EF) preferences.

Table 4 indicates that the MBTI introverted-sensing (IS), introverted-judging (IJ) and introverted-thinking (IT) preferences are significantly associated with the ECP emotional literacy scale, and the introverted-judging (IJ), introverted-sensing (IS) and introverted-thinking (IT) preferences are significantly associated with the ECP interpersonal relations scale other-evaluations. The introverted-thinking (IT) preference is significantly associated with the ECP self-esteem/self-regard scale (emotional competence other-evaluations) and CFSEI-AD personal self-esteem.

The ECP Total emotional competence scale is significantly associated with the extraverted-intuitive (EN) preference (in terms of the self-evaluations) and the introverted-judging (IJ) and introverted-thinking (IT) preferences (in terms of total emotional competence other-evaluations). Table 5 indicates the direction and nature of these relationships.

TABLE 1

Item analysis results: Cronbach Alpha coefficients FOR 360 ${ }^{\circ}$ EMOTIONAL COMPETENCY PROFILER CONSTRUCTS CURRENT BEHAVIOUR: SELF \& OTHERS

\begin{tabular}{lcc}
\hline ECP CONSTRUCT & $\begin{array}{c}\text { CRONBACH ALPHA } \\
\text { COEFFICIENTS } \\
\text { SELF (N=107) }\end{array}$ & $\begin{array}{c}\text { CRONBACH ALPHA } \\
\text { COEFFICIENTS } \\
\text { OTHER (N=340) }\end{array}$ \\
\hline Emotional Literacy & 0,51 & 0,75 \\
Self-esteem/self-regard & 0,67 & 0,74 \\
Self-management & 0,74 & 0,79 \\
Self-motivation & 0,61 & 0,74 \\
Change Resilience & 0,77 & 0,78 \\
Interpersonal Relations & 0,79 & 0,86 \\
Integration Head \& Heart & 0,71 & 0,78 \\
Total Emotional Competence & 0,92 & 0,95 \\
\hline
\end{tabular}

TABLE 2

Point bi-Serial CORRelation COEFFicients: MBTI COMBINATIONS AND CFSEI-AD

\begin{tabular}{|c|c|c|c|c|c|c|}
\hline & $\begin{array}{l}\text { EF } \\
\text { IF }\end{array}$ & $\begin{array}{l}\text { ET } \\
\text { IT }\end{array}$ & $\begin{array}{c}\text { MBTI } \\
\text { ES } \\
\text { IS }\end{array}$ & $\begin{array}{l}\text { EN } \\
\text { IN }\end{array}$ & $\begin{array}{l}\text { EJ } \\
\text { IJ }\end{array}$ & $\begin{array}{l}\text { EP } \\
\text { IP }\end{array}$ \\
\hline $\begin{array}{l}\text { CFSEI- } \\
\text { ADSocial }\end{array}$ & $\begin{array}{c}0,22 \\
(0,42)\end{array}$ & $\begin{array}{l}0,34 \\
(0,00)^{* * *}\end{array}$ & $\begin{array}{c}0,24 \\
(0,05)^{*}\end{array}$ & $\begin{array}{l}0,49 \\
(0,00) * * *\end{array}$ & $\begin{array}{c}0,28 \\
(0,01)^{* *}\end{array}$ & $\begin{array}{c}0,40 \\
(0,05)^{*}\end{array}$ \\
\hline General & $\begin{array}{c}0,01 \\
(0,97)\end{array}$ & $\begin{array}{c}0,21 \\
(0,05)^{*}\end{array}$ & $\begin{array}{c}0,08 \\
(0,52)\end{array}$ & $\begin{array}{l}0,44 \\
(0,01)^{* *}\end{array}$ & $\begin{array}{c}0,14 \\
(0,21)\end{array}$ & $\begin{array}{c}0,33 \\
(0,10)\end{array}$ \\
\hline Personal & $\begin{array}{l}-0,09 \\
(0,74)\end{array}$ & $\begin{array}{c}0,14 \\
(0,19)\end{array}$ & $\begin{array}{c}0,03 \\
(0,81)\end{array}$ & $\begin{array}{c}0,24 \\
(0,15)\end{array}$ & $\begin{array}{c}0,08 \\
(0,48)\end{array}$ & $\begin{array}{c}0,18 \\
(0,39)\end{array}$ \\
\hline Total & $\begin{array}{c}0,01 \\
(0,96)\end{array}$ & $\begin{array}{l}0,27 \\
(0,01)^{* *}\end{array}$ & $\begin{array}{c}0,13 \\
(0,27)\end{array}$ & $\begin{array}{l}0,50 \\
(0,00) * * *\end{array}$ & $\begin{array}{c}0,20 \\
(0,07)\end{array}$ & $\begin{array}{c}0,35 \\
(0,08)\end{array}$ \\
\hline
\end{tabular}

$* * * \mathrm{p}<0,001$
$* * \mathrm{p}<0,01$

${ }^{*} \mathrm{p}=0,05$ 
TABLE 3

MEANS: MBTI COMBINATIONS AND CFSEI-AD-DIRECTION OF SIGNIFICANT POINT BI-SERIAL CORRELATION COEFFICIENTS

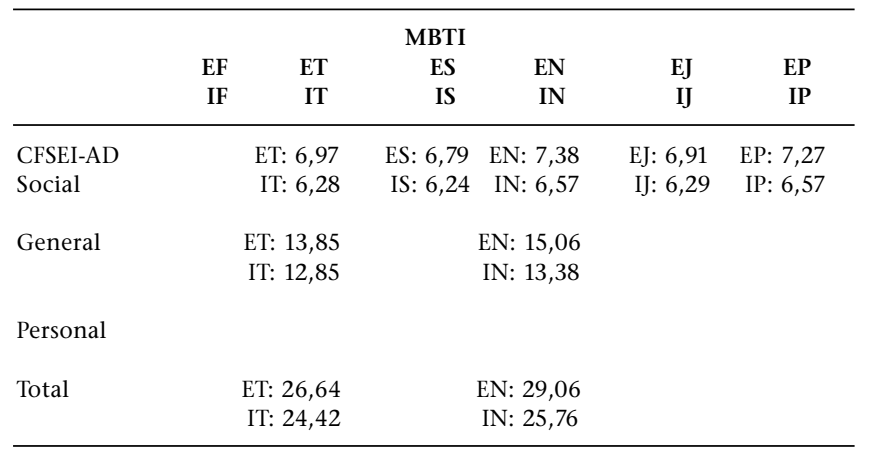

TABLE 4

PPOINT BI-SERIAL CORRELATION COEFFICIENTS: MBTI COMBINATIONS AND ECP CURRENTS BEHAVIOUR - SELF \& OTHERS

\begin{tabular}{|c|c|c|c|c|c|c|}
\hline & $\begin{array}{l}\text { EF } \\
\text { IF }\end{array}$ & $\begin{array}{l}\text { ET } \\
\text { IT }\end{array}$ & $\begin{array}{c}\text { MBTI } \\
\text { ES } \\
\text { IS }\end{array}$ & $\begin{array}{l}\text { EN } \\
\text { IN }\end{array}$ & $\begin{array}{l}\text { EJ } \\
\text { IJ }\end{array}$ & $\begin{array}{l}\text { EP } \\
\text { IP }\end{array}$ \\
\hline \multicolumn{7}{|l|}{ ЕСР } \\
\hline Self & $\begin{array}{c}0,01 \\
(0,96)\end{array}$ & $\begin{array}{c}0,14 \\
(0,17)\end{array}$ & $\begin{array}{c}0,08 \\
(0,51)\end{array}$ & $\begin{array}{c}0,23 \\
(0,18)\end{array}$ & $\begin{array}{l}-0,25 \\
(0,02)^{*}\end{array}$ & $\begin{array}{c}0,03 \\
(0,88)\end{array}$ \\
\hline Others & $\begin{array}{l}-0,04 \\
(0,89)\end{array}$ & $\begin{array}{l}-0,26 \\
(0,01)^{* *}\end{array}$ & $\begin{array}{l}-0,24 \\
(0,05)^{*}\end{array}$ & $\begin{array}{l}-0,20 \\
(0,22)\end{array}$ & $\begin{array}{l}-0,25 \\
(0,02)^{*}\end{array}$ & $\begin{array}{l}-0,11 \\
(0,60)\end{array}$ \\
\hline \multicolumn{7}{|c|}{ Self-esteem/Self-regard } \\
\hline Self & $\begin{array}{c}0,06 \\
(0,84)\end{array}$ & $\begin{array}{c}0,17 \\
(0,10)\end{array}$ & $\begin{array}{c}0,07 \\
(0,51)\end{array}$ & $\begin{array}{c}0,31 \\
(0,06)\end{array}$ & $\begin{array}{c}0,20 \\
(0,08)\end{array}$ & $\begin{array}{c}0,00 \\
(0,98)\end{array}$ \\
\hline Others & $\begin{array}{c}0,14 \\
(0,61)\end{array}$ & $\begin{array}{l}-0,20 \\
(0,05)^{*}\end{array}$ & $\begin{array}{l}-0,09 \\
(0,46)\end{array}$ & $\begin{array}{l}-0,30 \\
(0,07)\end{array}$ & $\begin{array}{l}-0,23 \\
(0,04)^{*}\end{array}$ & $\begin{array}{c}-0,12 \\
(0,55)\end{array}$ \\
\hline \multicolumn{7}{|c|}{ Self-management } \\
\hline Self & $\begin{array}{c}0,07 \\
(0,81)\end{array}$ & $\begin{array}{c}0,13 \\
(0,22)\end{array}$ & $\begin{array}{c}0,12 \\
(0,31)\end{array}$ & $\begin{array}{c}0,12 \\
(0,49)\end{array}$ & $\begin{array}{c}0,13 \\
(0,23)\end{array}$ & $\begin{array}{c}0,09 \\
(0,68)\end{array}$ \\
\hline Others & $\begin{array}{c}0,01 \\
(0,96)\end{array}$ & $\begin{array}{l}-0,09 \\
(0,38)\end{array}$ & $\begin{array}{l}-0,03 \\
(0,81)\end{array}$ & $\begin{array}{c}-0,19 \\
(0,26)\end{array}$ & $\begin{array}{l}-0,17 \\
(0,14)\end{array}$ & $\begin{array}{c}0,32 \\
(0,11)\end{array}$ \\
\hline \multicolumn{7}{|c|}{ Self-motivation } \\
\hline Self & $\begin{array}{c}0,33 \\
(0,23)\end{array}$ & $\begin{array}{c}0,25 \\
(0,02)^{*}\end{array}$ & $\begin{array}{c}0,19 \\
(0,13)\end{array}$ & $\begin{array}{c}0,39 \\
(0,02)^{*}\end{array}$ & $\begin{array}{c}0,27 \\
(0,02)^{*}\end{array}$ & $\begin{array}{c}0,26 \\
(0,20)\end{array}$ \\
\hline Others & $\begin{array}{c}0,11 \\
(0,69)\end{array}$ & $\begin{array}{l}-0,19 \\
(0,06)\end{array}$ & $\begin{array}{c}0,17 \\
-(0,15)\end{array}$ & $\begin{array}{c}-0,17 \\
(0,31)\end{array}$ & $\begin{array}{c}-0,20 \\
(0,07)\end{array}$ & $\begin{array}{c}-0,05 \\
(0,81)\end{array}$ \\
\hline \multicolumn{7}{|c|}{ Change Resilience } \\
\hline Self & $\begin{array}{c}0,32 \\
(0,24)\end{array}$ & $\begin{array}{c}-0,12 \\
(0,24)\end{array}$ & $\begin{array}{c}0,0 \\
(0,46)\end{array}$ & $\begin{array}{c}0,26 \\
(0,12)\end{array}$ & $\begin{array}{c}0,14 \\
(0,22)\end{array}$ & $\begin{array}{c}0,20 \\
(0,34)\end{array}$ \\
\hline Others & $\begin{array}{l}-0,08 \\
(0,77)\end{array}$ & $\begin{array}{l}-0,17 \\
(0,11)\end{array}$ & $\begin{array}{l}-0,28 \\
\left(0,02^{*}\right.\end{array}$ & $\begin{array}{c}0,12 \\
(0,47)\end{array}$ & $\begin{array}{c}-0,20 \\
(0,08)\end{array}$ & $\begin{array}{l}-0,00 \\
(0,99)\end{array}$ \\
\hline \multicolumn{7}{|c|}{ Interpersonal Relations } \\
\hline Self & $\begin{array}{c}0,51 \\
(0,05)\end{array}$ & $\begin{array}{c}0,12 \\
(0,25)\end{array}$ & $\begin{array}{c}0,07 \\
(0,56)\end{array}$ & $\begin{array}{c}0,36 \\
(0,03)^{*}\end{array}$ & $\begin{array}{c}0,15 \\
(0,19)\end{array}$ & $\begin{array}{c}0,27 \\
(0,19)\end{array}$ \\
\hline Others & $\begin{array}{l}{ }^{*} 0,13 \\
(0,65)\end{array}$ & $\begin{array}{l}-0,23 \\
(0,03)^{*}\end{array}$ & $\begin{array}{l}-0,29 \\
(0,02)^{*}\end{array}$ & $\begin{array}{l}-0,00 \\
(0,98)\end{array}$ & $\begin{array}{l}-0,24 \\
(0,03)^{*}\end{array}$ & $\begin{array}{c}0,04 \\
(0,84)\end{array}$ \\
\hline \multicolumn{7}{|c|}{ IntegrationHead \& Heart } \\
\hline Self & $\begin{array}{c}0,19 \\
(0,49)\end{array}$ & $\begin{array}{l}-0,00 \\
(0,98)\end{array}$ & $\begin{array}{l}-0,12 \\
(0,34)\end{array}$ & $\begin{array}{c}0,27 \\
(0,10)\end{array}$ & $\begin{array}{l}-0,06 \\
(0,62)\end{array}$ & $\begin{array}{c}0,31 \\
(0,13)\end{array}$ \\
\hline Others & $\begin{array}{l}-0,06 \\
(0,84)\end{array}$ & $\begin{array}{l}-0,17 \\
(0,11)\end{array}$ & $\begin{array}{l}-0,17 \\
(0,15)\end{array}$ & $\begin{array}{l}-0,13 \\
(0,45)\end{array}$ & $\begin{array}{l}-0,17 \\
(0,13)\end{array}$ & $\begin{array}{c}-0,12 \\
(0,56)\end{array}$ \\
\hline \multicolumn{7}{|l|}{ Total } \\
\hline Self & $\begin{array}{c}0,29 \\
(0,30)\end{array}$ & $\begin{array}{c}0,18 \\
(0,08)\end{array}$ & $\begin{array}{c}0,10 \\
(0,39)\end{array}$ & $\begin{array}{c}0,36 \\
(0,03)^{*}\end{array}$ & $\begin{array}{c}0,19 \\
(0,08)\end{array}$ & $\begin{array}{c}0,23 \\
(0,29)\end{array}$ \\
\hline Others & $\begin{array}{c}0,03 \\
(0,91)\end{array}$ & $\begin{array}{l}-0,24 \\
(0,02)^{*}\end{array}$ & $\begin{array}{l}-0,22 \\
(0,07)\end{array}$ & $\begin{array}{c}-0,17 \\
(0,32)\end{array}$ & $\begin{array}{l}-0,26 \\
(0,02)^{*}\end{array}$ & $\begin{array}{c}0,06 \\
(0,78)\end{array}$ \\
\hline
\end{tabular}

$* * * \mathrm{p}<0,001$
$* * \mathrm{p}<0,01$

$* \mathrm{p}=0,05$
TABLE 5

MEANS: MBTI COMBINATIONS AND ECP CURRENT BEHAVIOUR SELF \& OTHERS - DIRECTION OF SIGNIFICANT POINT BI-SERIAL CORRELATION COEFFICIENTS

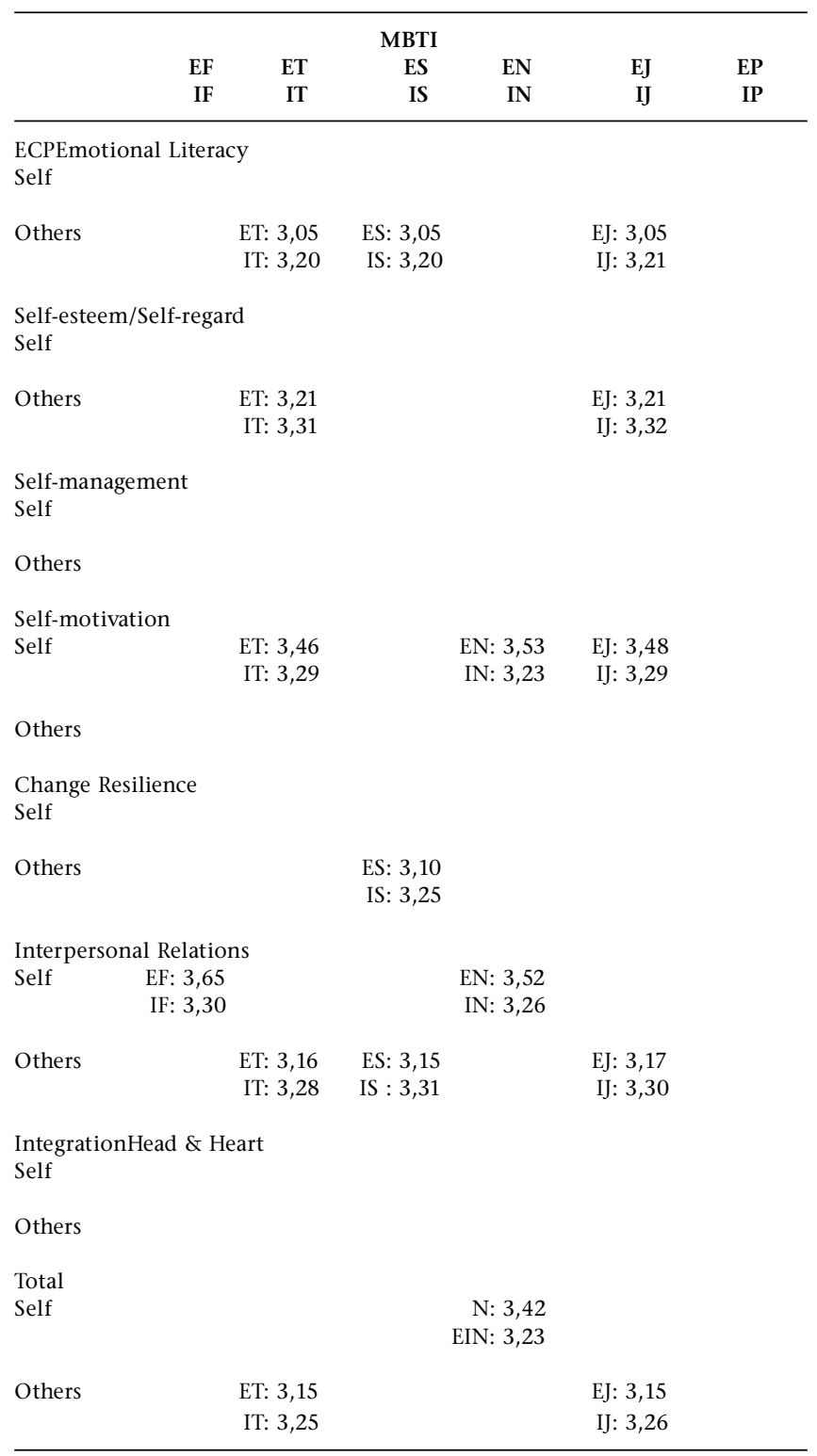

Pearson product-moment correlation coefficients were calculated to test whether self-esteem was related to emotional competence. Table 6 indicates significant associations between the CFSEI-AD general, personal and total self-esteem scales and the ECP change resilience, self-motivation, self-esteem/selfregard, interpersonal relations and total emotional competence scales.

Referring to Tables 2 and 4, the MBTI EN personality preference shows a significant relationship in terms of the CFSEI-AD Total Self-esteem (Table 2) and ECP Total Emotional Competence Self (Table 4) scales. Thus, in order to investigate the combined effect of the two independent variables (the EN personality preference and CFSEIAD Total self-esteem) on the dependent variable (ECP Total emotional competence Self), multiple linear regression was conducted to determine whether the EN personality preference and Total self-esteem act as predictors of Total Emotional Competence.

Table 7 indicates that Total self-esteem appears to be a more reliable predictor of emotional competence than the EN bipolar personality preference component. From an inspection 
of the regression results in Table 7 , it is evident that both the Total self-esteem construct and EN personality preference explain $30 \%$ of the variance in the Total Emotional Competence Self Current Behaviour attribute $\left(\mathrm{R}^{2}=0,29\right)$. However, only the predictor Total self-esteem was statistically significant in the regression equation: $\mathrm{F}(2,34)=7,26, \mathrm{p}=0,002$.

TABLE 6

Pearson product-moment correlations: CFSEI AND ECP CURRENT BEHAVIOUR - SELF \& OTHERS

\begin{tabular}{|c|c|c|c|c|}
\hline & & CFSEI-AD & & \\
\hline & Social & General Pers & nal & Total \\
\hline ECP & & & & \\
\hline Emotio & racy & & & \\
\hline Self & $\begin{array}{c}0,04 \\
(0,67)\end{array}$ & $\begin{array}{c}0,18 \\
(0,06)\end{array}$ & $\begin{array}{c}0,11 \\
(0,26)\end{array}$ & $\begin{array}{c}0,15 \\
(0,12)\end{array}$ \\
\hline Others & $\begin{array}{c}0,04 \\
(0,69)\end{array}$ & $\begin{array}{c}0,06 \\
(0,55)\end{array}$ & $\begin{array}{l}-0,12 \\
(0,22)\end{array}$ & $\begin{array}{l}-0,01 \\
(0,94)\end{array}$ \\
\hline Self-est & f-regard & & & \\
\hline Self & $\begin{array}{l}0,28 \\
(0,00)^{* * *}\end{array}$ & $\begin{array}{l}0,43 \\
(<, 0001)^{* * *}\end{array}$ & $\begin{array}{c}0,26 \\
(0,01)^{* *}\end{array}$ & $\begin{array}{l}0,42 \\
(<, 0001)^{* * *}\end{array}$ \\
\hline Others & $\begin{array}{c}0,01 \\
(0,91)\end{array}$ & $\begin{array}{l}-0,12 \\
(0,23)\end{array}$ & $\begin{array}{l}-0,25 \\
(0,01)^{* *}\end{array}$ & $\begin{array}{l}-0,18 \\
(0,07)\end{array}$ \\
\hline Self-ma & & & & \\
\hline Self & $\begin{array}{l}(0,12) \\
(0,22)\end{array}$ & $\begin{array}{l}0,35 \\
(0,00)^{* * *}\end{array}$ & $\begin{array}{c}0,18 \\
(0,06)\end{array}$ & $\begin{array}{l}0,30 \\
(0,00)^{* * *}\end{array}$ \\
\hline Others & $\begin{array}{c}0,05 \\
(0,59)\end{array}$ & $\begin{array}{l}-0,04 \\
(0,68)\end{array}$ & $\begin{array}{l}-0,07 \\
(0,48)\end{array}$ & $\begin{array}{l}-0,05 \\
(0,63)\end{array}$ \\
\hline Self-mo & & & & \\
\hline Self & $\begin{array}{l}(0,14) \\
(0,15)\end{array}$ & $\begin{array}{l}0,32 \\
(0,00)^{* * *}\end{array}$ & $\begin{array}{l}0,32 \\
(0,00)^{* * *}\end{array}$ & $\begin{array}{l}0,31 \\
(0,00)^{* * *}\end{array}$ \\
\hline Others & $\begin{array}{c}0,01 \\
(0,89)\end{array}$ & $\begin{array}{l}-0,00 \\
(0,98)\end{array}$ & $\begin{array}{l}-0,15 \\
(0,11)\end{array}$ & $\begin{array}{l}-0,07 \\
(0,48)\end{array}$ \\
\hline Change & & & & \\
\hline Self & $\begin{array}{l}(0,01) \\
(0,90)\end{array}$ & $\begin{array}{c}0,23 \\
(0,02)^{*}\end{array}$ & $\begin{array}{c}0,23 \\
(0,02)^{*}\end{array}$ & $\begin{array}{c}0,20 \\
(0,04)^{*}\end{array}$ \\
\hline Others & $\begin{array}{l}-0,06 \\
(0,54)\end{array}$ & $\begin{array}{l}-0,04 \\
(0,65)\end{array}$ & $\begin{array}{l}-0,04 \\
(0,65)\end{array}$ & $\begin{array}{l}-0,07 \\
(0,49)\end{array}$ \\
\hline Interpes & elations & & & \\
\hline Self & $\begin{array}{l}(0,18) \\
(0,07)\end{array}$ & $\begin{array}{l}0,27 \\
(0,01) * *\end{array}$ & $\begin{array}{l}0,27 \\
(0,01)^{* *}\end{array}$ & $\begin{array}{l}0,24 \\
(0,01)^{* *}\end{array}$ \\
\hline Others & $\begin{array}{c}0,04 \\
(0,67)\end{array}$ & $\begin{array}{c}0,01 \\
(0,94)\end{array}$ & $\begin{array}{l}-0,18 \\
(0,06)\end{array}$ & $\begin{array}{l}-0,07 \\
(0,50)\end{array}$ \\
\hline Integrat & d \& Heart & & & \\
\hline Self & $\begin{array}{l}(0,00) \\
(0,97)\end{array}$ & $\begin{array}{c}0,16 \\
(0,11)\end{array}$ & $\begin{array}{c}0,16 \\
(0,11)\end{array}$ & $\begin{array}{c}0,15 \\
(0,12)\end{array}$ \\
\hline Others & $\begin{array}{c}0,11 \\
(0,25)\end{array}$ & $\begin{array}{c}0,10 \\
(0,31)\end{array}$ & $\begin{array}{c}0,00 \\
(0,97)\end{array}$ & $\begin{array}{c}0,09 \\
(0,37)\end{array}$ \\
\hline Total & & & & \\
\hline Self & $\begin{array}{c}0,15 \\
(0,11)\end{array}$ & $\begin{array}{l}0,38 \\
(<, 0001) * * *\end{array}$ & $\begin{array}{l}0,24 \\
(0,01)^{* *}\end{array}$ & $\begin{array}{l}0,35 \\
(0,0002)^{* * *}\end{array}$ \\
\hline Others & $\begin{array}{c}0,04 \\
(0,70)\end{array}$ & $\begin{array}{l}-0,01 \\
(0,92)\end{array}$ & $\begin{array}{l}-0,15 \\
(0,13)\end{array}$ & $\begin{array}{l}-0,06 \\
(0,51)\end{array}$ \\
\hline
\end{tabular}

*** $\mathrm{p}=0,001$

** $p=0,01$

$* \mathrm{p}=0,05$
TABLE 7

MULTIPLE REGRESSION ON TOTAL EMOTIONAL COMPETENCY SCORES AGAINST MBTI EN-IN PERSONALITY PREFERENCE AND CFSEI-AD TOTAL SELF-ESTEEM

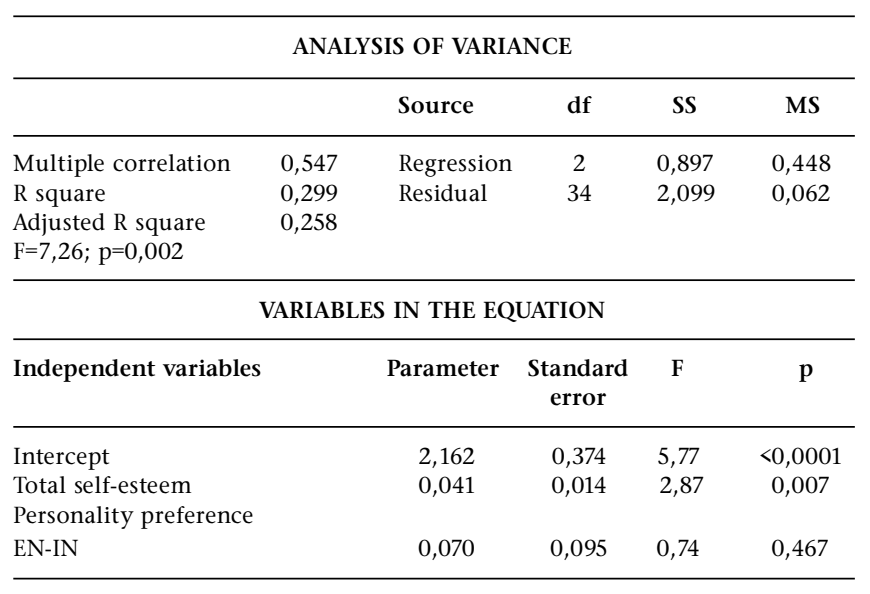

TABLE 8

T-TEST (LSD): PAIR-WISE COMPARISON OF THE MEANS OF THE ECP TOTAL EMOTIONAL COMPETENCE SELF \& OTHER GROUPS IN RESPECT OF CFSEI-AD TOTAL SELF-ESTEEM LEVELS

\begin{tabular}{|c|c|c|c|c|}
\hline $\begin{array}{l}\text { CFSEI-AD } \\
\text { LEVELS }\end{array}$ & $\mathbf{N}$ & T-GROUPING & MEAN & SD \\
\hline \multicolumn{5}{|c|}{ TOTAL EMOTIONAL COMPETENCE SELF } \\
\hline Very high & 18 & A & 3,46 & 0,201 \\
\hline High & 33 & A & 3,305 & 0,227 \\
\hline Intermediate & 46 & B & 3,264 & 0,278 \\
\hline Low & 9 & B & 3,182 & 0,332 \\
\hline \multicolumn{5}{|c|}{ TOTAL EMOTIONAL COMPETENCE OTHER } \\
\hline Very high & 18 & A & 3,178 & 0,228 \\
\hline High & 33 & A & 3,244 & 0,221 \\
\hline Intermediate & 46 & A & 3,198 & 0,194 \\
\hline Low & 9 & A & 3,278 & 0,171 \\
\hline
\end{tabular}

TOTAL EMOTIONAL COMPETENCE DIFFERENCE BETWEEN SELF \& OTHER TOTAL EC

\begin{tabular}{lccrr} 
Very high & 18 & A & 0,289 & 0,255 \\
High & 33 & B & 0,062 & 0,321 \\
Intermediate & 46 & B & 0,066 & 0,352 \\
Low & 9 & B & $-0,056$ & 0,332 \\
\hline
\end{tabular}

Note: Means with the same letter are not significantly different

TABLE 9

ANOVA: COMPARISON OF THE MEANS OF THE ECP TOTAL EMOTIONAL COMPETENCE SELF \& OTHER GROUPS IN RESPECT OF CFSEI-AD TOTAL SELF-ESTEEM

\begin{tabular}{|c|c|c|c|c|c|c|c|}
\hline & Source & $\begin{array}{l}\text { Dependent } \\
\text { variables }\end{array}$ & DF & Type III SS & MS & F & p \\
\hline $\begin{array}{l}\mathrm{F}(3 ; 102) \\
=3,47 ; \\
\mathrm{p}=0,02 *\end{array}$ & TSE & TECS & 3 & 0,684 & 0,228 & 3,47 & 0,02 * \\
\hline $\begin{array}{l}F(3 ; 102) \\
=0,54 ; \\
p=0,66\end{array}$ & TSE & TECO & 3 & 0,69 & 0,223 & 0,54 & 0,66 \\
\hline $\begin{array}{l}\mathrm{F}(3 ; 102) \\
=2,99 ; \\
\mathrm{p}=0,03 *\end{array}$ & TSE & DIFFEC & 3 & 0,96 & 0,319 & 2,99 & 0,03 * \\
\hline \multicolumn{8}{|l|}{${ }^{*} \mathrm{p}=<0,05$} \\
\hline $\begin{array}{l}\text { Note: } \\
\text { TSE (Total } \\
\text { TECS: Tota } \\
\text { TECO: Tota } \\
\text { DIFFC: Dif }\end{array}$ & $\begin{array}{l}\text { lf-esteem) } \\
\text { Emotional } \\
\text { Emotional } \\
\text {-ence betw }\end{array}$ & $\begin{array}{l}\text { ompetence Self } \\
\text { Competence Othe } \\
\text { en means of Tota }\end{array}$ & $r$ & hal Compet & Self & Total & \\
\hline
\end{tabular}


The results reported in Table 8 indicate that subjects with a very high Total self-esteem view themselves differently and more positively in terms of emotional competence than how others perceive them. The analysis of variance in Table 9 indicates that CFSEI-AD Total Self-esteem has a significant effect on the Total Emotional Competence Self ratings. Respondents with a very high Total Self-esteem rating scored themselves significantly higher on the ECP scale than those with low and intermediate CFSEI-AD Total Self-esteem ratings.

\section{DISCUSSION}

In the introduction, it was pointed out that a limited amount of research had been conducted to study the association between personality preferences, self-esteem and the ability to demonstrate emotionally competent behaviour. The objective of this study was therefore to investigate the relationship between the MBTI twelve dominant personality preferences (EF-IF, ET-IT, ES-IS, EN-IN, EJ-IJ, EP-IP), the CFSEI-AD self-esteem constructs and the ECP emotional competence current behaviour constructs, since these three variables offer the possibility of predicting individuals' level of emotional competence.

The first step in the analysis of the data was to investigate whether there were statistically significant associations between the MBTI personality preferences, the CFSEI-AD scales and the ECP scales. Overall, the results indicated a positive relationship between the MBTI personality preferences and the CFSEI-AD self-esteem scales with the exception of the extraverted-feeling (EF) and introverted-feeling (IF) personality preferences. This may be due to the under-representation of these types. De Beer (1997) reports findings of an analysis of type preference in South Africa from a database of 6,452 people which confirm EJ, ET, IJ and IS as the most common types for Black and White South Africans. In the present study, it was again found that the EJ, ET, IJ and IS types predominated.

It appears from the results that others perceived the introverted types as more emotionally competent than the extraverted types. This may be due to the introspective and quiet nature of these personality preferences, which may lead to them being perceived as being more in control of their emotions, and thus more emotionally competent. On the other hand, the extraverted personality preference types themselves appeared to have higher confidence in their level of emotional competence. These personality types are action-oriented, confident and sociable and may tend to show and verbalise their emotional nature (Myers et al., 1998). The extraverted-intuitive (EN) personality preference types also showed a higher level of confidence in their ability to understand and demonstrate caring and compassion for people. This positive self-evaluation could be ascribed to their action-oriented, energetic, sociable and adaptable nature (Myers et al, 1998). A study conducted by Higgs (2001) regarding the relationship between the MBTI personality preferences and emotional intelligence also indicated that the dominant mental function of intuition $(\mathrm{N})$, and the associated personality types, are significantly related to higher levels of emotional intelligence. Furthermore, within this analysis, both the mental function of intuition $(\mathrm{N})$ and the attitude extraversion (E) were with emotional intelligence elements identified as developable.

The MBTI introverted-sensing (IS) personality preference is a combination of the dominant attitudes and functions of the introverted-judging (IJ) personality preference. The typical characteristics of this personality preference (being introspective, quiet and thoughtful realists) could offer an explanation for the positive relationship with the emotional competence evaluations by others of subjects' emotional literacy, change resilience and interpersonal relations. The "Other" subjects could have experienced the quiet and introspective nature of the IJ and IS personality preference as being in control of their emotions, open to change and willing to co-operate with others. The actual inward experiences of the introverted-judging and introverted-sensing personality preferences are not always obvious as they usually show their secondary function preference to the outside world, namely their reserved thinking and feeling nature (Myers et al, 1998).

The MBTI introverted-thinking (IT) personality preference is a combination of the dominant attitudes and functions of the introverted-perceiving (IP) personality preference. The typical characteristics of this personality preference (being quiet, introspective, reflective and adaptable reasoners and harmonisers respectively) could explain the positive relationship with the emotional competence evaluations by others of the subjects' emotional literacy and self-esteem/selfregard. Others could have experienced the quiet, reflective, introspective and adaptable nature of the IT and IP personality preference as being in control of their emotions and having a positive self-regard. The actual inward experiences of the introverted-perceiving and introverted-intuitive personality preferences are not always obvious as they usually show their secondary function preference to the outside world, namely their reserved thinking and feeling nature (Myers et al, 1998).

The absence of a positive relationship between the MBTI personality preferences and the ECP Integration of Head and Heart Self and Other scales is not so surprising, as the MBTI personality preferences imply the use of preferred dominant functions and the Integration of Head and Heart emotional competency implies the balanced use of all four mental functions (Myers et al, 1998; Wolmarans \& Martins, 2001).

The lack of a strong and comprehensive relationship between the MBTI personality preferences and the emotional competency scales of the ECP may partly be due to the psychometric limitations of the MBTI (Higgs, 2001; Furnham \& Stringfield, 1993) and its moderate proven ability to predict behaviour (McCrae \& Costa, 1998). It may also be due to the methodological limitations in comparing ipsative and normative instruments and the nature of the current sample and its potential bias in terms of gender and race. However, valuable information pertaining to the ESTJ (EJ, ET) and ISTJ (IJ, IS) personality preferences were provided, given that this is the dominant personality profile of technical environments in a typical Western society (Myers et al, 1998).

The second step in the analysis of the data was to investigate whether there were statistically significant associations between the CFSEI-AD scales and the ECP scales. The findings indicated an overall lack of significant relationships between the emotional competence evaluations by others and the subjects' self-evaluations of their general, personal and social self-esteem. A possible explanation for the negative relationship between the Self-esteem/self-regard ECP Other scale and the CFSEI-AD Personal self-esteem scale could be ascribed to self-esteem being a personal, internally generated aspect of the personality and therefore not easily measurable by others (Battle, 1992). It is interesting to note that subjects with lower personal self-esteem, and who most probably came across as more reserved, were perceived by others as having a high regard for their own worth (Wolmarans \& Martin, 2001). Another perspective may be that subjects with lower Personal self-esteem may have under-rated themselves and thus appeared to be more positively perceived and evaluated by others on the ECP Self-esteem/self-regard scale (Sosick \& Megerian, 1999).

Furthermore, the findings imply that emotional competence is closely related to the affective component of self-awareness and one's sense of psychological well-being. It appears that the understanding and regulation of emotions in the self-evaluative process may facilitate positive affect, which in turn is related to General and Personal self-esteem (Battle, 1992). In this regard, the absence of a significant relationship between the CFSEI-AD 
self-esteem scales and the ECP Emotional Literacy scale is quite surprising. A probable reason for this may be the low itemreliability measurement (Cronbach alpha coefficient $=0,51$ ) on the Emotional Literacy scale.

The third step in the analysis of the data was to establish whether the twelve MBTI personality preferences and the CFSEI-AD Total self-esteem scale could predict emotional competence. Self-esteem appeared to be the best predictor of emotional competence. The apparent lack of prediction ability demonstrated by the MBTI personality preferences could be due to the fact that the MBTI is not aimed at predicting behaviour, but rather at explaining behaviour and being an aid towards personality development (Myers et al., 1998). Finally, the findings confirmed the effect of self-esteem on the self-evaluations of self-raters in multi-rater assessments such as the ECP, namely that self-raters with very high self-esteem may tend to over-inflate their selfevaluations (Yammarino \& Atwater, 1997). Theron and Roodt (2001) also discovered that leniency bias in self-ratings was related to self-esteem.

In conclusion, it must be kept in mind that the results were obtained from a sample of participants in the manufacturing industry, which would probably limit the generality of the findings. Therefore, these findings need to be verified with other samples and measuring instruments before drawing conclusions about the relationship between personality preferences, self-esteem and emotional competence in the South African organisational context. However, the results of this study provide valuable data regarding the relationship between personality preferences, self-esteem and emotional competence which could be seen as the first step in investigating the effect of these personality variables on the ability of leaders to demonstrate emotionally competent behaviour.

The Industrial Psychologist is facing the challenge to see emotional competence, personality preferences and self-esteem concepts integrated in leader development curriculums and multi-rater assessment tools. Accepting that much of the competence building which impacts effective leadership taps into one's emotional domains, may be the first hurdle as industrial psychologists build learning strategies that enable the development of emotionally competent leaders (Coetzee, 2005; Dearborn, 2002; Myers \& McCaulley, 1992).

It is recommended that future researchers replicate this study by substituting different personality, self-esteem and emotional intelligence inventories to investigate the effect of personality variables on the ability to demonstrate emotionally competent behaviour. Future researchers could also expand this study by broadening the sample to include a more balanced representation of the different race and gender groups and the sixteen MBTI personality types in a wider variety of organisations. Further research is also necessary to better understand the antecedents and correlates of South African leaders' emotional competence.

\section{REFERENCES}

Ashkanasy, N.M. \& Daus, C.S. (2005). Rumors of the death of emotional intelligence in organizational behavior are vastly exaggerated. Journal of Organizational Behavior, 26, 441-452.

Bar-On, R. (1997). Bar-On Emotional Quotient Inventory: Facilitator's Resource Manual. Toronto: Multi-Health Systems.

Battle, J. (1992). Culture - free Self-esteem Inventories for Children and Adults. Texas: Pro-Ed.

Baumeister, R.F. \& Leary, M.R. (1995). The need to belong: Desire for interpersonal attachments as a fundamental human motivation. Psychological Bulletin, 117, 497-529.
Carr, P.G., De la Garza, J.M. \& Vorster, M.C. (2002). Relationship between personality traits and performance for engineering and architectural professionals providing design services. Journal of Management in Engineering, 18 (4), 158-167.

Ciarrochi, J.V., Chan, A.Y.C., \& Caputi, P. (2000). A critical evaluation of the emotional intelligence construct. Personality and Individual Differences, 28 (3), 539-561.

Coetzee, M. (2004). Confirmatory factor analysis of the CFSEI-AD for Black and White South Africans. Unpublished article, Department Industrial \& Organisational Psychology, Unisa: Pretoria.

Coetzee, M. (2005). The relationship between personality preferences, self-esteem and emotional competence. Unpublished Doctoral thesis, University of South Africa, Pretoria.

Collins, V.L. 2001. Emotional intelligence and leadership success. Unpublished Doctoral thesis, University of Nebraska, Lincoln, NE.

Creed, W.E.D. \& Scully, M.A. (2001). Songs of ourselves: Employees' deployment of social identity in everyday workplace encounters. Journal of Management Inquiry, 9, 391412.

Dearborn, K. (2002). Studies in emotional intelligence redefine our approach to leadership development. Public Personnel Management, 31 (4), 523-530.

De Beer, J. (1997). Dealing with personal and cultural transitions. Paper presented at APT XII Association for Psychological Type International Conference, Boston, MA.

Dulewicz, S.V. \& Higgs, M.J. (1999). Can emotional intelligence be measured and developed? Leadership and Organization Development, 20 (5), 242-252.

Dulewicz, V. \& Higgs, M. (2000). Emotional intelligence: A review and evaluation study. Journal of Managerial Psychology, 15 (4), 341-372.

Du Toit, F., Coetzee, S. \& Visser, D. (2005). The relationship between personality type and sense of coherence among technical workers. Southern African Business Review, 9 (1), 5165.

Eisenberg, N., Cumberland, A. \& Spinrad, T.L. (1998). Parental socialization of emotion. Psychological Inquiry, 9, 241-273.

Fineman, S. (2000). Emotions in organizations. London: Sage.

Fox, S. \& Spector, P.E. (2000). Relations of emotional intelligence, practical intelligence, general intelligence, and trait affectivity with interview outcomes: it's not just " $G$ ". Journal of Organizational Behavior, 21, 203-220.

Furnham, A. \& Stringfield, P. (1993). Personality and occupational behaviour: Myers-Briggs Type Indicator correlations of management practices in two cultures. Human Relations, 46 (7), 827-848.

Garrety, K., Badham, R., Morrigan, V., Rifkin, \& Zanko, M. (2003). The use of personality typing in organizational change: Discourse, emotions and the reflexive subject. Human Relations, 56 (2), 211-235.

George, J.M. (2000). Emotions and leadership: The role of emotional intelligence. Human Relations, 53, 1027-1041.

Goleman, D. (2001). An EI-based theory of performance. In C. Cherniss \& D. Goleman (Eds.), The emotionally intelligent workplace (p. 27). San Francisco: Jossey-Bass.

Hewitt, J.P. (2002). The social construction of self-esteem. In C.R. Snyder \& S.J. Lopez (Eds.), Handbook of positive psychology (pp. 135-147). New York: Oxford University Press.

Higgs, M. (2001). Is there a relationship between the MyersBriggs Type Indicator and emotional intelligence? Journal of Managerial Psychology, 16 (7), 509-533.

Jung, C.G. (1921/1990). Psychological types. In Collected works, Vol. 6. Princeton, NJ: Princeton University Press.

Kanfer, R. \& Kantrowitz, T.M. (2002). Emotion regulation: Command and control of emotion in work life. In R.G. Lord, R.J. Klimoski, \& R. Kanfer (Eds.), Emotions in the workplace: Understanding the structure and role of emotions in organizational behaviour (pp 429-472). New York: Jossey-Bass. 
Kennedy, R.B. \& Kennedy, D.A. (2004). Using the Myers-Briggs Type Indicator in career counselling. Journal of Employment Counselling, 41, 38-45.

Kinicki, A. \& Kreitner, R. (2006). Organizational behavior: Key concepts, skills and best practices. New York: McGraw-Hill.

Leary, M.R. (1999a). Making sense of self-esteem. Current directions in Psychological Science, 8, 32-35.

Leary, M.R. (1999b). The social and psychological importance of self-esteem. In R.M. Kowalski \& M.R. Leary (Eds.), The social psychology of emotional and behavioural problems (pp. 197221). Washington: American Psychological Association.

Lee, S. \& Klein, H.J. (2002). Relationships between conscientiousness, self-efficacy, self-deception, and learning over time. Journal of Applied Psychology, 87 (6), 1175-1182.

Locke, E.A. (2005). Why emotional intelligence is an invalid concept. Journal of Organizational Behavior, 26, 425-431.

Lopes, P.N., Brackett, M.A., Nezlek, J.B., Schutz, A., Sellin, I. \& Salovey, P. (2004). Emotional intelligence and social interaction. Personality and Social Psychology Bulletin, 30 (8), 1018-1034.

Lopes, P.N., Salovey, P., Cote, S. \& Beers, M. (2005). Emotion regulation ability and the quality of social interaction. Emotion, 5 (1),113-118.

Mandell, B. \& Pherwani, S. (2003). Relationship between emotional intelligence and transformational leadership style: A gender comparison. Journal of Business and Psychology, 17 (3), 387-404.

Martinez-Pons, M. (2000). Emotional intelligence as a selfregulatory process: A social-cognitive view. Imagination, Cognition, and Personality, 19, 331-350.

Mayer, J.D. \& Salovey, P. (1997). What is emotional intelligence: Implications for educators. In P. Salovey \& D. Sluyter (Eds.), Emotional development, emotional literacy, and emotional intelligence: Educational implications (pp. 3-31). New York: Basic Books.

Martin, J. (2005). Organisational behaviour and management. Unit Kingdom: Thomson Learning.

McCrae, R. \& Costa, P. (1988). Re-interpreting the Myers-Briggs Type Indicator from the perspective of the five-factor model of personality. Journal of Personality, 57, 17-40.

Mischel, W. (1999). Personality coherence and dispositions in a cognitive-affective personality system (CAPS) approach. In D. Cervone \& Y. Shoda (Eds.), The coherence of personality: Social-cognitive bases of consistency, variability, and organization (pp. 37-66). New York: Guilford Press.

Myers, I.B. (1987). Introduction to type: A description of the theory and applications of the Myers-Briggs Type Indicator. Palo Alto, California: Consulting Psychologists Press, Inc.

Myers, I.B. \& McCaulley, M.H. (1992). Manual: A guide to the development and use of the Myers-Briggs Type Indicator. Palo Alto, California: Consulting Psychologists Press, Inc.

Myers, I.B., McCaulley, M.H., Quenk, N.L., \& Hammer, A.L. (1998). MBTI Manual: A guide to the development and use of the Myers-Briggs Type Indicator. Palo Alto, California: Consulting Psychologists Press, Inc.
Palmer, B.R., Gardner, L., \& Stough, C. (2003). Measuring emotional intelligence in the workplace with the Swinburne University Emotional Intelligence Test. Published in the Proceedings of the First International Conference on Contemporary Management: Emotional Intelligence in Organizations, September, Swinburne University of Technology, Australia.

Pinder, R. \& Herriot, P. (1990). Assessment centre dimensions, personality and aptitudes. Journal of Occupational Psychology, 63, 211-216.

Saarni, C. (1997). Emotional competence and self-regulation in childhood. In P. Salovey \& D.J. Sluyter (Eds.). Emotional development and emotional intelligence: Educational implications (pp. 35-66). New York: BasicBooks.

Saarni, C. (1999). The development of emotional competence. New York: Guilford Press.

Salovey, P. \& Mayer, J.D. (1990). Emotional intelligence. Imagination, Cognition, and Personality, 9, 185-211.

SAS Institute. (2000). The SAS System for Windows: Release 9.1. Cary: SAS Institute Inc.

Schutte, N.S., Malouff, J.M., Simunek, M., Hollander, S., \& McKenley, J. (2002). Characteristic emotional intelligence and emotional well-being. Cognition and Emotion, 16, 769-785.

Shaughnessy, J.J. \& Zechmeister, E.B. (1997). Research methods in psychology. New York: McGraw-Hill.

Sosick, J.J. \& Megerian, L.E. (1999). Understanding leader emotional intelligence and performance: The role of selfother agreement on transformational leadership perceptions. Group \& Organization Management, 24 (3), 367-390.

Stuart, A.D. \& Pauquet, A. (2001). Emotional intelligence as a determinant of leadership potential. Journal of Industrial Psychology, 27 (3), 30-34.

Theron, D. \& Roodt, G. (2001). An evaluation of the 360 project management competency assessment questionnaire. Journal of Industrial Psychology, 27 (2), 51-56.

Tice, D.M. (1993). The social motivations of people with low selfesteem. In R.F. Baumeister (Ed.), Self-esteem: The puzzle of low self-regard (pp.37-54). New York: Plenum Press.

Tredoux, C. \& Durrheim, K. (2002). Numbers, hypotheses \& conclusions: A course in statistics for the social sciences. Cape Town: UCT Press.

Worline, M.C., Wrzesniewski, A., \& Rafaeli, A. (2002). Courage and work: Breaking routines to improve performance. In R.G. Lord, R.J. Klimoski, \& R. Kanfer (Eds.), Emotions in the workplace: Understanding the structure and role of emotions in organizational behaviour (pp. 295-330). New York: Jossey-Bass.

Wolmarans, S. (2002). Emotional competencies of the future. Obtained directly from the author.

Wolmarans, S. \& Martins, N. (2001). The 360 degree Emotional Competency Profiler. Johannesburg: Organisational Diagnostics and Learning Link International.

Yammarino, F.J. \& Atwater, L.E. (1997). Do managers see themselves as others see them? Implications of self-other rating agreement for human resources management. Organizational Dynamics, 25 (4), 35-36. 